\title{
Imaging of Tie2 with a fluorescently labeled small molecule affinity ligand
}

\author{
Peter David Koch ${ }^{1,3}$, Maaz S. Ahmed ${ }^{1,3}$, Rainer H. Kohler ${ }^{1}$, Ran Li ${ }^{1}$, Ralph \\ Weissleder ${ }^{1,2,4}$
}

1.Center for Systems Biology, Massachusetts General Hospital, Boston, MA 02115

2.Department of Systems Biology, Harvard Medical School, Boston, MA 02115

3.These authors contributed equally

4.Correspondence: rweissleder@mgh.harvard.edu

\section{Supplementary Figures}

Toxicity of Rebastinib Imaging Agents

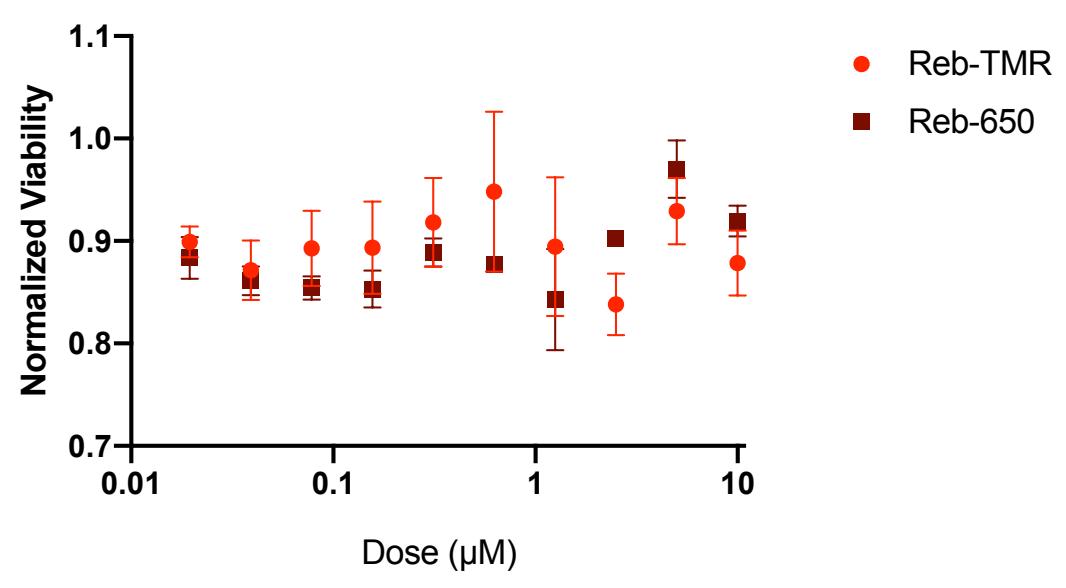

Figure S1: Toxicity of Reb-TMR and Reb-650. HUVEC cells were treated with either Reb-TMR or Reb-650 for 16 hours at the indicated doses. Minimal toxicity was seen. Data plotted as mean $+/$-s.d., $N=2$. 
a.

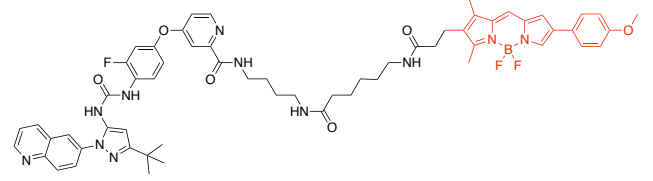

Reb-TMR

b.

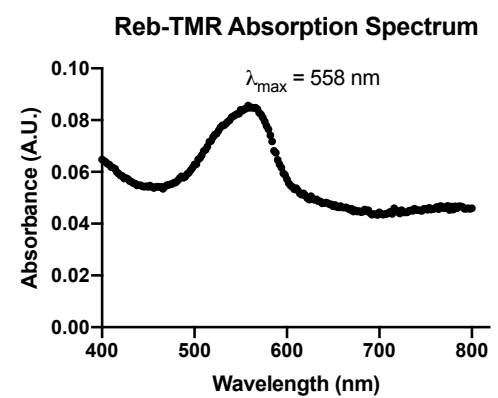

Reb-TMR Emission

C.

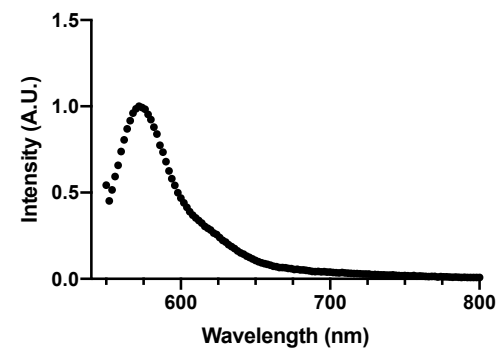

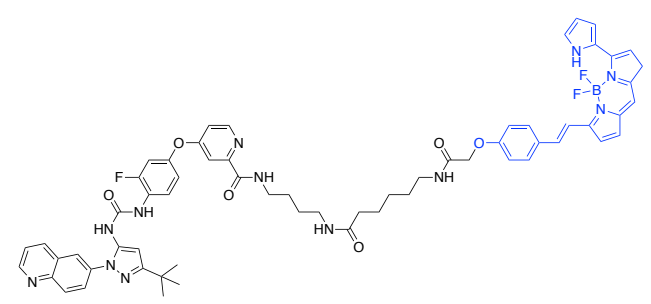

Reb-650

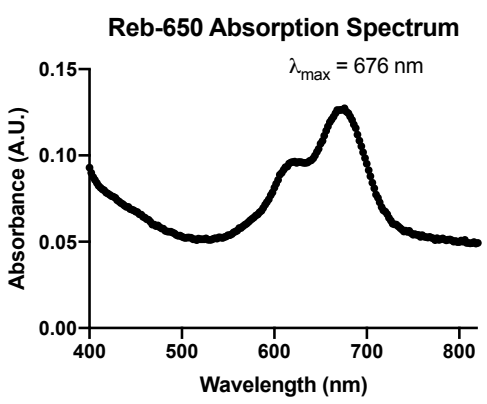

Reb-650 Emission

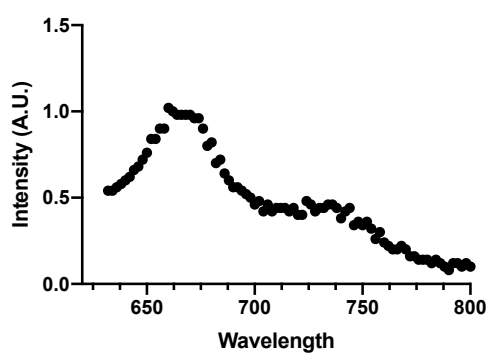

Figure S2: Photophysical properties of Reb-TMR (left) and Reb-650. a: chemical structures of Reb-TMR and Reb-650. b. Absorption spectrum of Reb-TMR and Reb-650. c. Fluorescent intensity emission spectrum of Reb-TMR and Reb-650. 


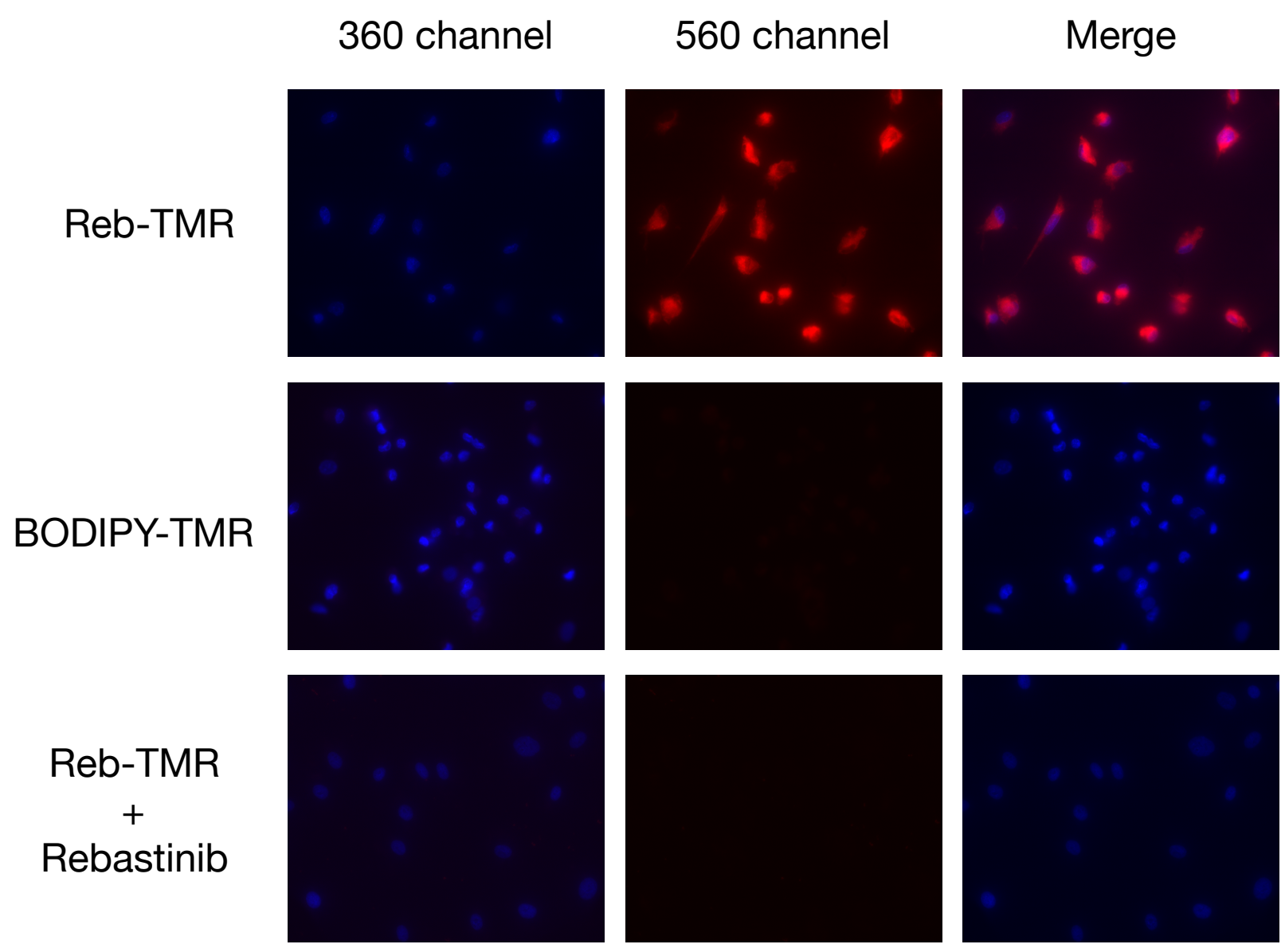

Figure S3: Treatment of HUVEC cells with either $100 \mathrm{nM}$ Reb-TMR (top) or $100 \mathrm{nM}$ free BODIPY-TMR dye (middle). Pre-treatment of cells with $10 \mu \mathrm{M}$ unlabeled rebastinib eliminates fluorescent Reb-TMR signal (bottom), comparable to free dye control. 


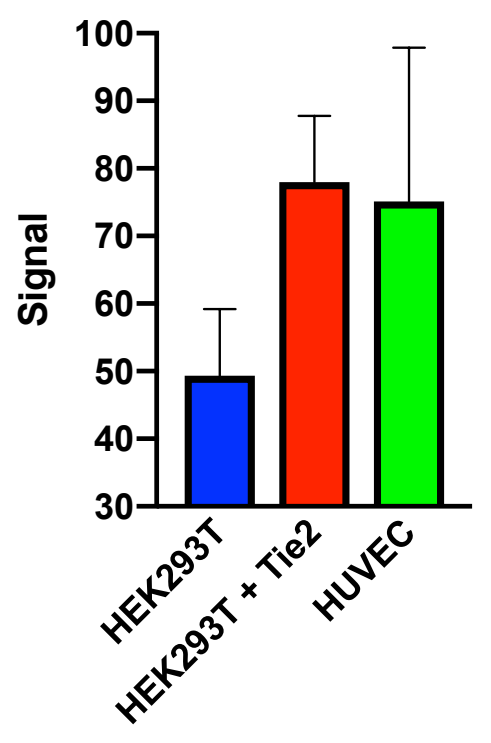

Figure S4: HUVEC (Tie2+), HEK293T (Tie2-) and HEK293T transfected with Tie2 plasmid were treated with increasing doses of Reb-TMR. Average fluorescent intensities per dose were calculated. Plotted is mean +/- S.D., $\mathrm{N}=3$ 


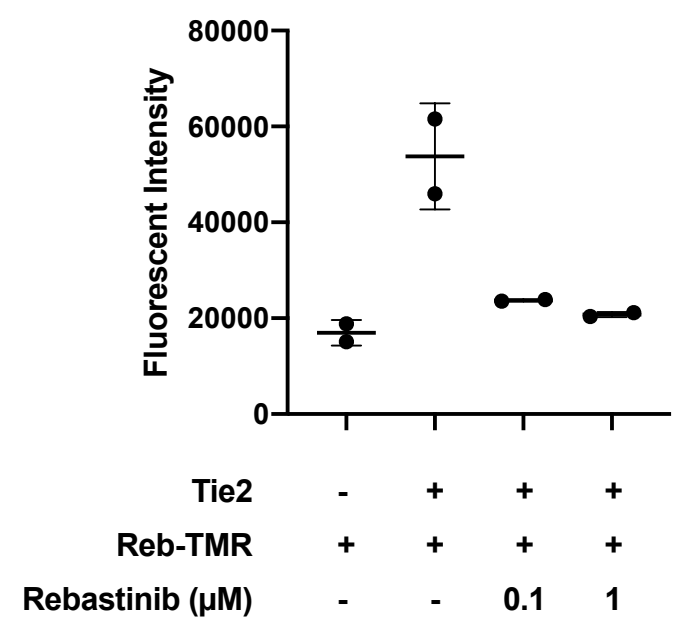

Figure S5: Biochemical fluorescent intensity of Reb-TMR (0.8 uM) in the absence or presence of recombinant Tie2. Leftmost point corresponds to intensity of Reb-TMR in PBS, and right points correspond to intensity of Reb-TMR with Tie2, and in increasing concentrations of unlabeled rebastinib $(0,0.1,1,10 \mathrm{uM})$. Reported is mean over $\mathrm{N}=2$ wells. Error bars correspond to S.D. 


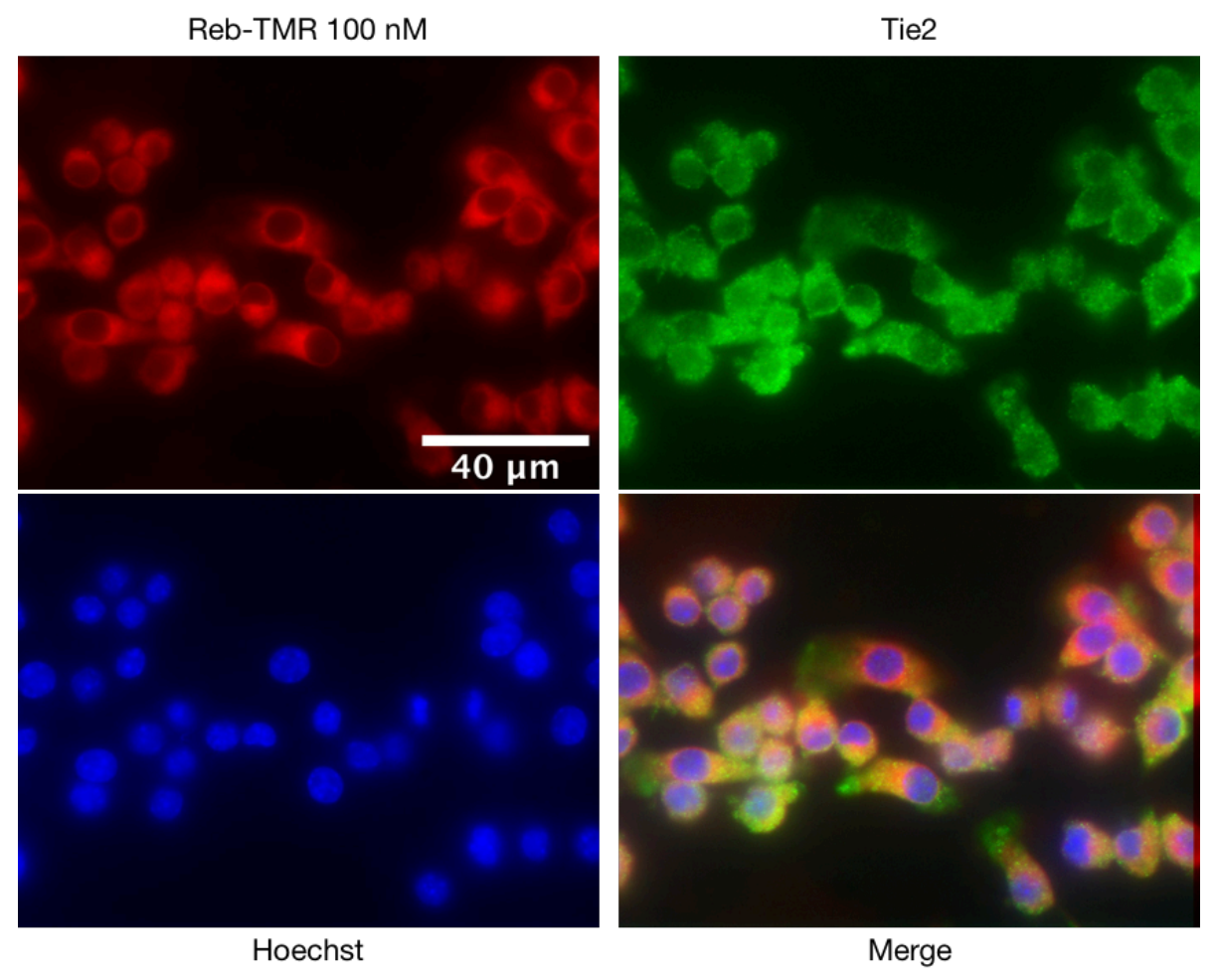

Figure S6: Co-localization in RAW264.7 cells. Staining of Reb-TMR (red) in RAW264.7 macrophages along with co-stain for Tie2 (green). Nuclei are indicated by the Hoechst stain (blue). 


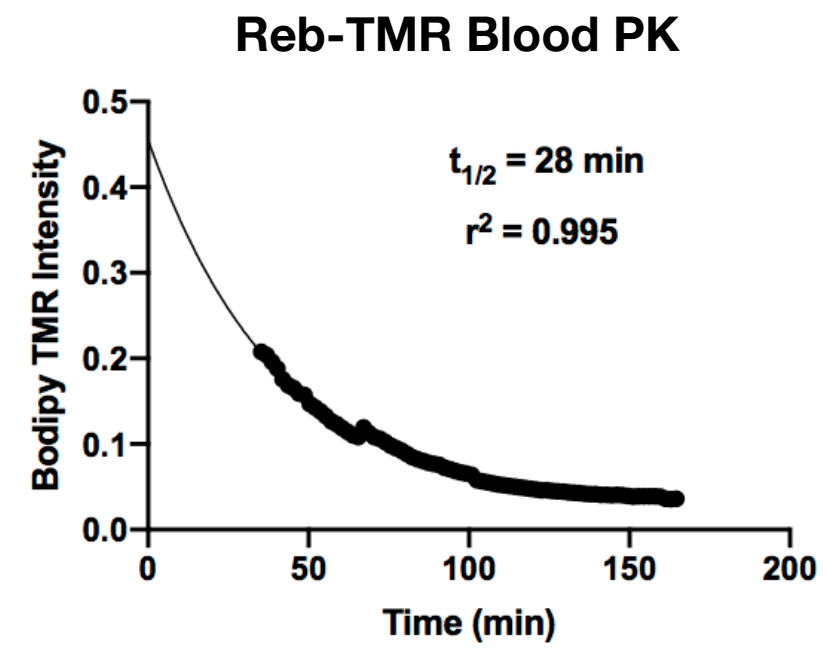

Figure S7: Measurement of blood half-life of Reb-TMR. 


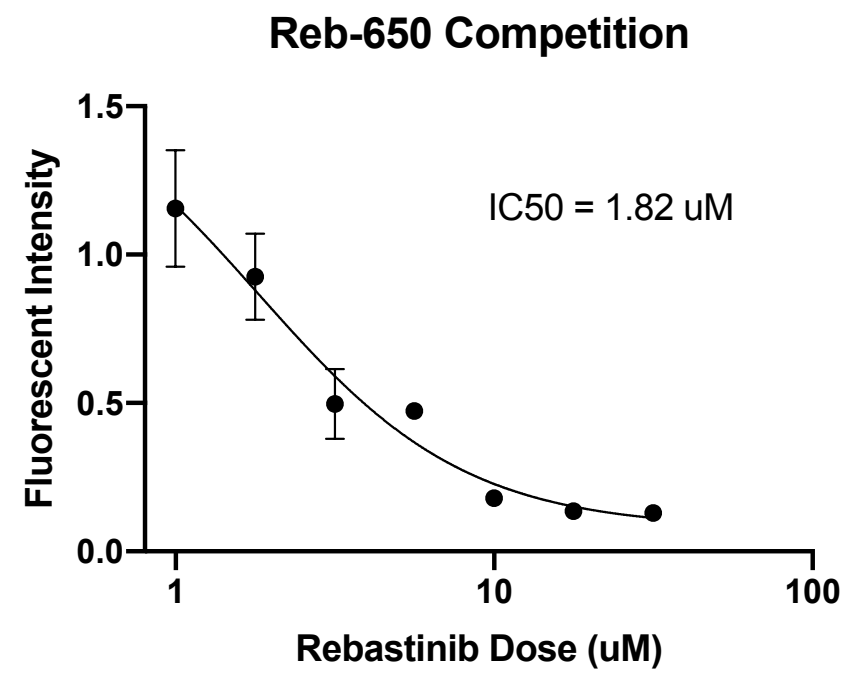

Figure S8: Competition of Rebastinib-BODIPY 650 with unlabeled rebastinib. HUVEC cells were treated with $100 \mathrm{nM}$ Rebastinib-BODIPY 650, in combination with unlabeled rebastinib. Average single cell BODIPY 650 intensity per wall was calculated, $N=2$ wells, error bars $=$ S.D. Unlabeled rebastinib could compete out Rebastinib-BODIPY 650 , with IC50 $=1.8 \mu \mathrm{M}$. 


\begin{tabular}{|c|c|c|c|c|c|}
\hline $\begin{array}{l}\text { Original } \\
\text { name in } \\
\text { manuscript }\end{array}$ & $\begin{array}{l}\text { Revised } \\
\text { name }\end{array}$ & $\operatorname{Ex} / \operatorname{Em}(\mathrm{nm})$ & Filter Info & $\begin{array}{l}\text { Used to } \\
\text { image }\end{array}$ & $\begin{array}{l}\text { Imaging } \\
\text { system }\end{array}$ \\
\hline GFP/YFP & 490 channel & $488 / 510$ & $\begin{array}{l}\text { Ex: 405/473/559 } \\
\text { Dichroic } \\
\text { Em: BA490-540 }\end{array}$ & $\begin{array}{l}\text { Tie2- } \\
\text { GFP }\end{array}$ & FV1000 \\
\hline mAPPLE & 560 channel & $568 / 592$ & $\begin{array}{l}\text { Ex: } 405 / 473 / 559 \\
\text { Dichroic } \\
\text { Em: BA575-620 }\end{array}$ & $\begin{array}{l}\text { Reb- } \\
\text { TMR }\end{array}$ & FV1000 \\
\hline Су3 & 560 channel & $554 / 568$ & $\begin{array}{l}\text { Ex: } 520-560 \\
\text { Em: } 560-630\end{array}$ & $\begin{array}{l}\text { Reb- } \\
\text { TMR }\end{array}$ & Operetta, IXM \\
\hline Cy5 & 650 channel & $649 / 666$ & $\begin{array}{l}\text { Ex: } 620-640 \\
\text { Em: } 650-700\end{array}$ & $\begin{array}{l}\text { Reb-650; } \\
\text { Reb-SiR }\end{array}$ & Operetta, IXM \\
\hline Hoechst & 360 channel & $361 / 497$ & $\begin{array}{l}\text { Ex: } 360-400 \\
\text { Em: } 410-480\end{array}$ & $\begin{array}{l}\text { Hoechst, } \\
\text { nuclear } \\
\text { dye }\end{array}$ & Operetta, IXM \\
\hline Су3 & 560 channel & $554 / 568$ & $\begin{array}{l}\text { Ex: } 511-551 \\
\text { Em: } 573-613\end{array}$ & $\begin{array}{l}\text { Reb- } \\
\text { TMR }\end{array}$ & $\begin{array}{l}\text { BX63, } \\
\text { Modified } \\
\text { Olympus } \\
\text { Deltavision }\end{array}$ \\
\hline $\begin{array}{l}\text { Alexa Fluor } \\
647\end{array}$ & 650 channel & $649 / 666$ & $\begin{array}{l}\text { Ex: } 608-648 \\
\text { Em: } 672-712\end{array}$ & $\begin{array}{l}\text { Anti-Tie2 } \\
\text { Antibody }\end{array}$ & $\begin{array}{l}\text { BX63, } \\
\text { Modified } \\
\text { Olympus } \\
\text { Deltavision }\end{array}$ \\
\hline Hoechst & 360 channel & $361 / 497$ & $\begin{array}{l}\text { Ex: } 380.5-392.5 \\
\text { Em: } 417-477\end{array}$ & $\begin{array}{l}\text { Hoechst, } \\
\text { nuclear } \\
\text { dye }\end{array}$ & $\begin{array}{l}\text { BX63, } \\
\text { Modified } \\
\text { Olympus } \\
\text { Deltavision }\end{array}$ \\
\hline
\end{tabular}

Table S1: Microscopy Information 


\section{General Considerations}

All commercially available compounds were purchased and used as received. NHS Ester dyes were purchased from Thermo Fisher Scientific and SiROOH synthesis has been described in the literature ${ }^{1-6}$. Reaction mixtures were purified using a Biotage ${ }^{\circledR}$ SNAP Bio C18 $300 \AA 10 \mathrm{~g}$ on a Biotage ${ }^{\circledR}$ Isolera with a gradient composed of water $(0.1 \%$ formic acid) and acetonitrile $(0.1 \%$ formic acid $)$ for reversed-phase chromatography, starting from $5 \%$ to $100 \%$ acetonitrile $\left(0.1 \%\right.$ formic acid). ${ }^{1} \mathrm{H}$ and ${ }^{13} \mathrm{C}$ NMR spectra were recorded on a Bruker AC-400 MHz spectrometer. High-performance liquid chromatography was done with a gradient of water $(0.1 \%$ formic acid) and acetonitrile $(0.1 \%$ formic acid) and separated with a XTerra MS C18 Column, $125 \AA, 5$ $\mu \mathrm{m}, 4.6 \mathrm{~mm} \times 50 \mathrm{~mm}$ and mass ions were detected on a Waters 3100 Mass Detector.

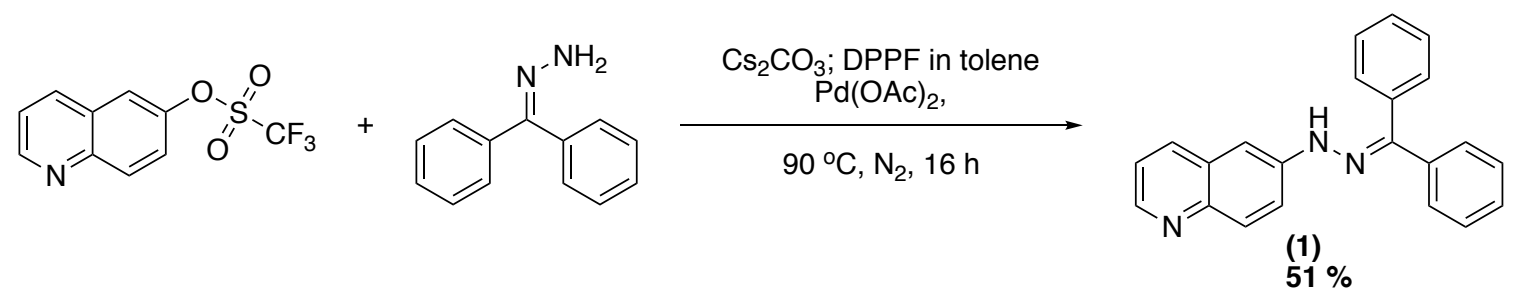

Synthesis of 1. Toluene was degassed with a stream of $\mathrm{N}_{2}$ for 3 hours prior to use. 6Quinolinyl trifluoromethanesulfonate $(2 \mathrm{~g}, 7.2 \mathrm{mmol}, 1.0 \mathrm{eq})$, benzophenone hydrazone (1.8.g, $9.3 \mathrm{mmol}, 1.3 \mathrm{eq}$ ), DPPF (126 mg, $0.23 \mathrm{mmol}, 0.032 \mathrm{eq})$, and $\mathrm{Cs}_{2} \mathrm{CO}_{3}(3.8 \mathrm{~g}$, $11.8 \mathrm{mmol}, 1.6 \mathrm{eq})$ was suspended in toluene $(50 \mathrm{~mL})$ under a $\mathrm{N}_{2}$ environment. To this reaction $\mathrm{Pd}(\mathrm{OAc})_{2}(0.67 \mathrm{mg}, 0.003 \mathrm{mmol})$ in $1 \mathrm{~mL}$ toluene was added and heated to 90 $\mathrm{C}$ overnight. The reaction was cooled and concentrated to a residue. The reaction residue was purified via normal phase chromatography with a gradient from hexanes to ethyl acetate. Fractions of similar purity were combined and concentrated to yield the desired product 1 (orange-red solid, $1.2 \mathrm{~g}, 51 \%$ yield, $98 \%$ purity) which was stored under $\mathrm{Ar}$ at $-80 \mathrm{C}$. $\mathrm{m} / \mathrm{z}$ calculated: 323.14 ; (M)+ found: 325.59 . ${ }^{1} \mathrm{H} \mathrm{NMR}\left(400 \mathrm{MHz}, \mathrm{CDCl}_{3}\right)$ $\delta 8.50(\mathrm{~d}, J=3.5 \mathrm{~Hz}, 1 \mathrm{H}), 7.82(\mathrm{dd}, J=8.4,4.6 \mathrm{~Hz}, 2 \mathrm{H}), 7.68(\mathrm{~s}, 1 \mathrm{H}), 7.51(\mathrm{~d}, J=7.6$ $\mathrm{Hz}, 2 \mathrm{H}), 7.46-7.31(\mathrm{~m}, 3 \mathrm{H}), 7.29(\mathrm{~s}, 1 \mathrm{H}), 7.19(\mathrm{q}, J=9.3,7.8 \mathrm{~Hz}, 5 \mathrm{H}), 7.10(\mathrm{dt}, J=$ 6.8, 3.4 Hz, 2H), 7.02 (d, J = 7.7 Hz, 1H), $2.20(\mathrm{~s}, 1 \mathrm{H}) .{ }^{13} \mathrm{C} \mathrm{NMR}\left(101 \mathrm{MHz}, \mathrm{CDCl}_{3}\right) \delta$ $147.13,145.64,144.29,142.49,138.09,134.46,132.50,130.36,129.74,129.43$, $129.04,128.38,128.27,126.68,125.30,121.50,119.04,106.09$. 
<smiles>c1ccc(C(=NNc2ccc3ncccc3c2)c2ccccc2)cc1</smiles>

(1)

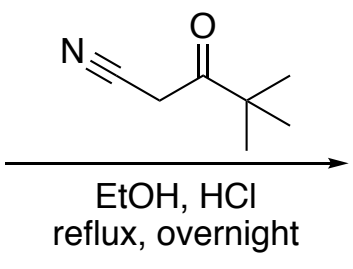

reflux, overnight

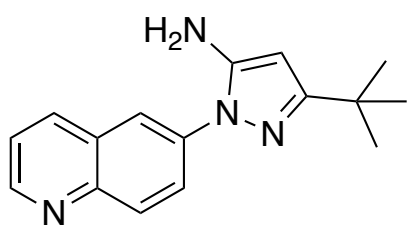

(2)

$93 \%$

Synthesis of 2.1 ( $1.5 \mathrm{~g}, 4.6 \mathrm{mmol}, 1.0 \mathrm{eq})$ and pivaloylacetonitrile $(870 \mathrm{mg}, 7.0 \mathrm{mmol}$, $1.5 \mathrm{eq}$ ) was stirred well in ethanol $(20 \mathrm{~mL})$. To this reaction $\mathrm{HCl}(3 \mathrm{~mL})$ was added and heated to reflux overnight. The reaction was cooled and concentrated to a residue. The reaction residue was extracted with water and diethyl ether. The aqueous layer was neutralized with saturated $\mathrm{Na}_{2} \mathrm{CO}_{3}$ and extracted with ethyl acetate $(3 \times 100 \mathrm{~mL})$. The organic fractions were combined and dried with $\mathrm{Na}_{2} \mathrm{SO}_{4}$ and concentrated to yield a reaction residue. The residue was purified via normal phase chromatography with a gradient of dichloromethane and methanol, ranging from $0.1 \%$ to $2 \%$ methanol. Fractions of similar purity were combined and concentrated to yield the desired product 2 (orange-red solid, $1.1 \mathrm{~g}, 93 \%$ yield, $94 \%$ purity) which was stored under $\mathrm{Ar}$ at $-80 \mathrm{C}$. $\mathrm{m} / \mathrm{z}$ calculated: 266.15 ; (M)+ found: 267.02. ${ }^{1} \mathrm{H}$ NMR $\left(400 \mathrm{MHz}\right.$, DMSO- $\left.d_{6}\right) \delta 8.89(\mathrm{~d}, J=$ $3.8 \mathrm{~Hz}, 1 \mathrm{H}), 8.41(\mathrm{~d}, J=8.3 \mathrm{~Hz}, 1 \mathrm{H}), 8.18(\mathrm{~d}, J=1.7 \mathrm{~Hz}, 1 \mathrm{H}), 8.12(\mathrm{~s}, 2 \mathrm{H}), 7.55$ (dd, $J=$ 8.4, $4.2 \mathrm{~Hz}, 1 \mathrm{H}), 5.51(\mathrm{~s}, 1 \mathrm{H}), 1.29(\mathrm{~s}, 9 \mathrm{H}) .{ }^{13} \mathrm{C}$ NMR $\left(101 \mathrm{MHz}, \mathrm{DMSO}-\mathrm{d}_{6}\right) \delta 161.52$, $150.10,147.66,145.65,137.45,136.07,129.78,128.05,125.49,121.89,118.96,87.37$, $31.94,30.21$. 


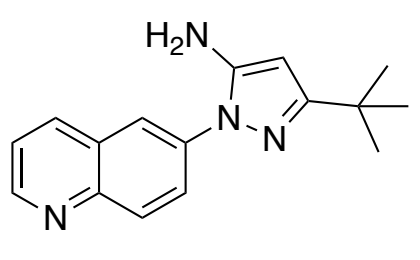

(2)<smiles>CC(C)(C)c1cc(NC(=O)OCC(Cl)(Cl)Cl)n(-c2ccc3ncccc3c2)n1</smiles>

$(3)$

Synthesis of 3.2 ( $571 \mathrm{mg}, 4.6 \mathrm{mmol}, 1.0 \mathrm{eq})$, pyridine $(0.57 \mathrm{~mL}, 7.1 \mathrm{mmol}, 3.3 \mathrm{eq})$, and DMAP $(7.9 \mathrm{mg}, 0.065 \mathrm{mmol}, 0.03 \mathrm{eq})$ were stirred well in dichloromethane $(40 \mathrm{~mL})$ and cooled to $-10 \mathrm{C}$. To this 2,2,2-trichloroethyl chloroformate $(0.42 \mathrm{~mL}$ in $12 \mathrm{~mL} \mathrm{DCM})$ was added dropwise over a period of 20 minutes. Afterwards, the reaction was stirred at room temperature for an hour. To the reaction water $(40 \mathrm{~mL})$ was added as stirred for 20 mins. The reaction residue was extracted with brine. The organic fractions were combined and dried with $\mathrm{Na}_{2} \mathrm{SO}_{4}$ and concentrated to yield a reaction residue. The residue was purified via reverse phase chromatography. Fractions of similar purity were combined and concentrated to yield the desired product $3(749.0 \mathrm{mg}, 37 \%$ yield, $92 \%$ purity) which was stored under $\mathrm{Ar}$ at $-80 \mathrm{C}$. $\mathrm{m} / \mathrm{z}$ calculated: 440.06 ; (M)-found: $439.38 .{ }^{1} \mathrm{H}$ NMR $\left(400 \mathrm{MHz}, \mathrm{CDCl}_{3}\right) \delta 8.68(\mathrm{~d}, J=4.2 \mathrm{~Hz}, 1 \mathrm{H}), 8.61(\mathrm{~b}, 1 \mathrm{H}), 7.92(\mathrm{dd}, J=12.7,8.6$ $\mathrm{Hz}, 2 \mathrm{H}), 7.63(\mathrm{~d}, J=7.6 \mathrm{~Hz}, 1 \mathrm{H}), 7.29(\mathrm{dd}, J=8.3,4.3 \mathrm{~Hz}, 1 \mathrm{H}), 6.41(\mathrm{~s}, 1 \mathrm{H}), 4.79(\mathrm{~s}$, $2 \mathrm{H}), 1.30$ (d, $J=1.2 \mathrm{~Hz}, 9 \mathrm{H}) .{ }^{13} \mathrm{C}$ NMR $\left(101 \mathrm{MHz}, \mathrm{CDCl}_{3}\right) \delta$ 162.05, 150.87, 149.18, $144.94,135.49,135.33,134.55,129.52$, 127.04, 125.55, 121.39, 120.76, 96.12, 94.02, $73.86,31.53,29.26$. 
<smiles>COC(=O)c1cc(Cl)ccn1</smiles><smiles>CC(C)(C)CCCCNC(=O)O</smiles><smiles>CCCCNCCCCNC(=O)c1cc(Cl)ccn1</smiles>

$88 \%$

Synthesis of 4. Methyl 4-chloropicolinate (1.0 g, $5.8 \mathrm{mmol}, 2.0 \mathrm{eq})$, N-Boc-1,4butanediamine $(2.2 \mathrm{~g}, 11.7 \mathrm{mmol}, 4.0 \mathrm{eq})$, and $\mathrm{MgCl}(279 \mathrm{mg}, 2.9 \mathrm{mmol}, 1.0 \mathrm{eq})$ were stirred well in THF $(5 \mathrm{~mL})$ for 2 hours. To the reaction water $(5 \mathrm{~mL})$ and $1 \mathrm{~N} \mathrm{HCl}(10 \mathrm{~mL})$ were added. The reaction residue was extracted with ethyl acetate $(3 \times 20 \mathrm{~mL})$. The reaction mixture was washed with brine. The organic fractions were combined and dried with $\mathrm{MgSO}_{4}$ and concentrated to yield a reaction residue. The residue was purified via normal phase chromatography with a gradient of dichloromethane and methanol, ranging from $0 \%$ to $2 \%$ methanol. Fractions of similar purity were combined and concentrated to yield the desired product $4(1.7 \mathrm{~g}, 88 \%$ yield, $91 \%$ purity) which was stored under Ar at -80 C. $\mathrm{m} / \mathrm{z}$ calculated: 350.12 ; $(\mathrm{M}+\mathrm{Na})+$ found: 350.33 . ${ }^{1} \mathrm{H}$ NMR (400 $\left.\mathrm{MHz} \mathrm{CDCl}_{3}\right) \delta 8.37(\mathrm{~d}, J=5.2 \mathrm{~Hz}, 1 \mathrm{H}), 8.13(\mathrm{~d}, J=2.0 \mathrm{~Hz}, 1 \mathrm{H}), 7.96(\mathrm{~d}, J=7.3 \mathrm{~Hz}$, $1 \mathrm{H}), 7.36$ (dd, $J=5.4,2.0 \mathrm{~Hz}, 1 \mathrm{H}), 4.52(\mathrm{~s}, 1 \mathrm{H}), 3.42(\mathrm{q}, J=6.7 \mathrm{~Hz}, 2 \mathrm{H}), 3.10$ (d, $J=6.7$ $\mathrm{Hz}, 2 \mathrm{H}), 1.66-1.45(\mathrm{~m}, 4 \mathrm{H}), 1.37$ (s, 9H). ${ }^{13} \mathrm{C}$ NMR (101 MHz, CDCl 3 ) $\delta 163.26$, 156.12, 151.48, 149.02, 146.11, 126.44, 123.04, 40.35, 39.32, 28.55, 27.70, 27.13. 


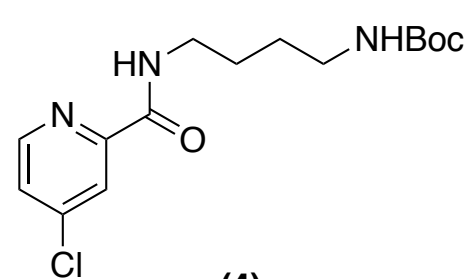

(4)

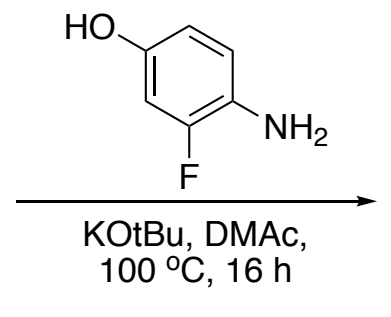<smiles>CC(C)(C)OC(=O)NCCCCNC(=O)c1cc(Oc2ccc(N)c(F)c2)ccn1</smiles>

(5)

Synthesis of 5. 2-Fluoro-4-methoxyaniline $(1.7 \mathrm{~g}, 13.3 \mathrm{mmol}, 1.0 \mathrm{eq})$ was suspended in DMAc $(5 \mathrm{~mL})$ cooled to $0 \mathrm{C}$ under $\mathrm{N}_{2}$ atmosphere. To this reaction KOtBu $(1.5 \mathrm{~g}, 13.3$ $\mathrm{mmol}, 1.0 \mathrm{eq})$ was added. This was stirred at $0 \mathrm{C}$ for 30 minutes. After which, $4(1.7 \mathrm{~g}$, $5.1 \mathrm{mmol}, 0.39 \mathrm{eq}$ ) was added and the reaction was heated to $100 \mathrm{C}$ overnight. The reaction was next cooled to room temperature and a saturated solution of $\mathrm{LiCl}$ (10 $\mathrm{mL})$ was added. The reaction mixture extracted with ethyl acetate $(3 \times 100 \mathrm{~mL})$. The organic layer was washed with water $(3 \times 100 \mathrm{~mL})$ and brine $(3 \times 100 \mathrm{~mL})$. The organic layer was dried with $\mathrm{MgSO}_{4}$ and concentrated to yield a reaction residue. The residue was purified via reverse phase chromatography. Fractions of similar purity were combined and concentrated to yield the desired product $5(1.96 \mathrm{~g}, 92 \%$ yield, $98 \%$ purity) which was stored under $\mathrm{Ar}$ at $-80 \mathrm{C}$. $\mathrm{m} / \mathrm{z}$ calculated: 417.18 ; (M+FA)-found: 463.42 and (2M + FA) ]- found: 881.75. ${ }^{1} \mathrm{H} \mathrm{NMR}\left(400 \mathrm{MHz}, \mathrm{CDCl}_{3}\right) \delta 8.22(\mathrm{~d}, J=5.6 \mathrm{~Hz}, 1 \mathrm{H}), 8.10$ $(\mathrm{t}, J=6.2 \mathrm{~Hz}, 1 \mathrm{H}), 7.58-7.50(\mathrm{~m}, 1 \mathrm{H}), 6.80(\mathrm{dd}, J=5.7,2.2 \mathrm{~Hz}, 1 \mathrm{H}), 6.74-6.61(\mathrm{~m}$, $2 \mathrm{H}$ ), $6.57(\mathrm{dd}, J=8.5,2.5 \mathrm{~Hz}, 1 \mathrm{H}), 5.04(\mathrm{~d}, J=6.0 \mathrm{~Hz}, 1 \mathrm{H}), 4.05(\mathrm{~s}, 2 \mathrm{H}), 3.33(\mathrm{~d}, J=6.6$ $\mathrm{Hz}, 2 \mathrm{H}), 3.02(\mathrm{~d}, J=6.5 \mathrm{~Hz}, 2 \mathrm{H}), 1.48(\mathrm{dt}, J=32.2,7.2 \mathrm{~Hz}, 4 \mathrm{H}), 1.30(\mathrm{~s}, 9 \mathrm{H}) .{ }^{13} \mathrm{C}$ NMR $\left(101 \mathrm{MHz}, \mathrm{CDCl}_{3}\right) \delta 166.67,163.93,156.08,152.36,152.02,149.95,149.55,144.32$, $133.10,117.18,113.68,109.70,109.03,78.79,40.09,39.03,28.32,27.37,26.88$. 


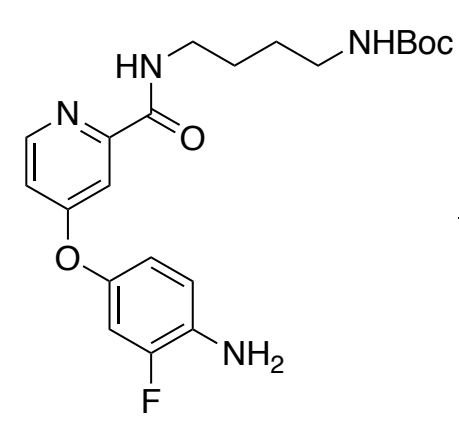

(5)
(3), DIPEA, DMSO, $70{ }^{\circ} \mathrm{C}, 4 \mathrm{hr}$

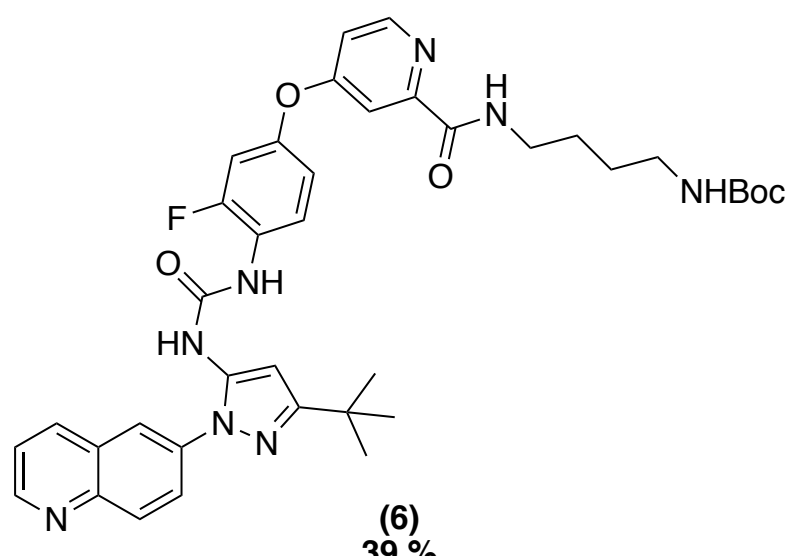

$39 \%$

Synthesis of 6.3 (350 mg, $0.79 \mathrm{mmol}, 1.0 \mathrm{eq}), 5$ (297 mg, $0.71 \mathrm{mmol}, 0.9 \mathrm{eq})$, DIPEA $(0.3 \mathrm{~mL}, 1.74 \mathrm{mmol}, 2.2 \mathrm{eq})$ was suspended in DMSO $(5 \mathrm{~mL})$ heated to $70 \mathrm{C}$. The reaction was monitored by LCMS for 4 hours. DMSO was separated using a Waters Sep-Pak C-18. The residue was purified via normal phase chromatography with a gradient of dichloromethane and methanol, ranging from $0 \%$ to $10 \%$ methanol. Fractions of similar purity were combined and concentrated to yield the desired product 6 (197 mg, $39 \%$ yield, $77 \%$ purity) which was stored under Ar at -80 C. $\mathrm{m} / \mathrm{z}$ calculated: 710.33; (M)+ found: 711.67 and (M - BoC)+ found: 611.62. ${ }^{1} \mathrm{H}$ NMR (400 MHz, CDCl $/$ /DMSOd6) $\delta 9.00(\mathrm{~s}, 1 \mathrm{H}), 8.82(\mathrm{~s}, 1 \mathrm{H}), 8.71(\mathrm{~d}, J=4.9 \mathrm{~Hz}, 1 \mathrm{H}), 8.51(\mathrm{~d}, J=8.7 \mathrm{~Hz}, 1 \mathrm{H}), 8.30$ $(\mathrm{d}, J=5.6 \mathrm{~Hz}, 1 \mathrm{H}), 8.24-8.10(\mathrm{~m}, 3 \mathrm{H}), 8.01(\mathrm{t}, J=6.2 \mathrm{~Hz}, 1 \mathrm{H}), 7.55(\mathrm{dd}, J=8.6,5.1$ $\mathrm{Hz}, 1 \mathrm{H}), 7.50(\mathrm{~d}, J=2.5 \mathrm{~Hz}, 1 \mathrm{H}), 6.91(\mathrm{dd}, J=5.7,2.6 \mathrm{~Hz}, 1 \mathrm{H}), 6.78$ (dd, $J=9.0,2.6$ $\mathrm{Hz}, 1 \mathrm{H}), 6.73-6.63(\mathrm{~m}, 1 \mathrm{H}), 6.54(\mathrm{~s}, 1 \mathrm{H}), 4.54(\mathrm{~s}, 2 \mathrm{H}), 3.29(\mathrm{~d}, J=6.6 \mathrm{~Hz}, 2 \mathrm{H}), 3.05(\mathrm{~d}$, $J=6.5 \mathrm{~Hz}, 2 \mathrm{H}), 1.33(\mathrm{~d}, J=18.1 \mathrm{~Hz}, 22 \mathrm{H})$. (See Figure S9) 


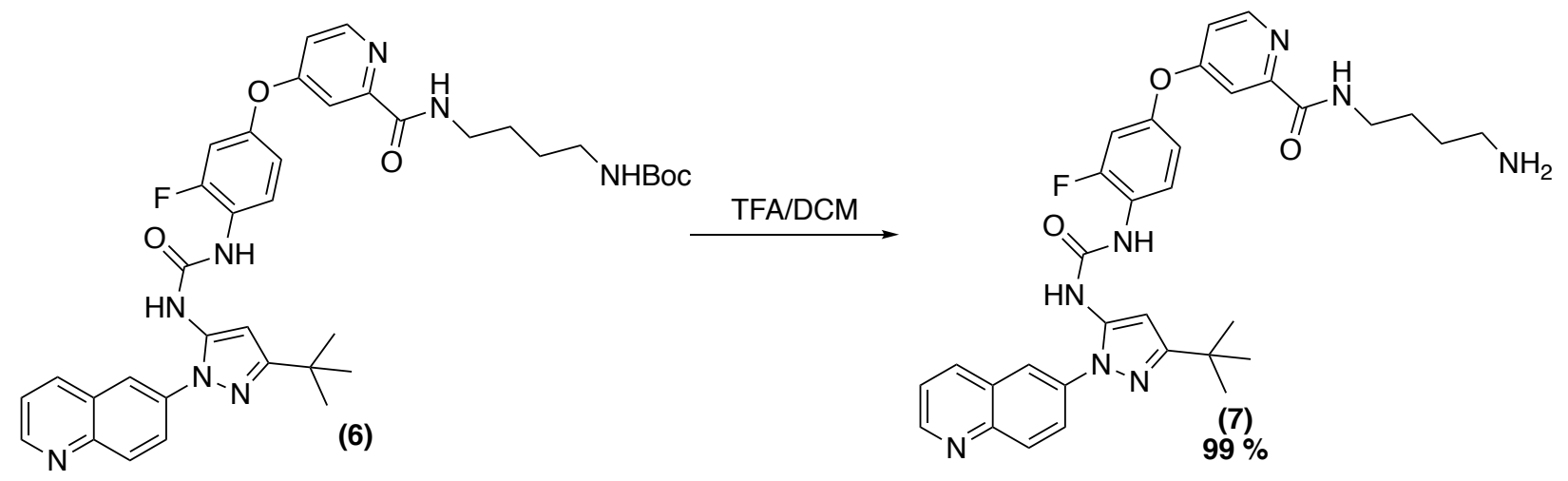

Synthesis of $7.6(137 \mathrm{mg}, 0.19 \mathrm{mmol}, 1.0 \mathrm{eq})$ was suspended in dichloromethane (3 $\mathrm{mL})$. To this TFA (1 mL) was added dropwise. The reaction was monitored by LCMS for 10 minutes. After which the reaction was concentrated to produce a residue. The residue was purified via reverse phase chromatography. Fractions of similar purity were combined and concentrated to yield the desired product $7(115 \mathrm{mg}, 99 \%$ yield, $95 \%$ purity) which was stored under $\mathrm{Ar}$ at $-80 \mathrm{C} . \mathrm{m} / \mathrm{z}$ calculated: 610.28 ; $(\mathrm{M})+$ found: 610.28 and $(\mathrm{M}-\mathrm{BoC})+$ found: 609.54. ${ }^{1} \mathrm{H}$ NMR $(400 \mathrm{MHz}$, MeOD/DMSO-d 6$) \delta 9.79(1 \mathrm{H}), 9.72(1 \mathrm{H})$, $9.62(1 \mathrm{H}), 9.53(1 \mathrm{H}), 9.16(2 \mathrm{H}), 8.82(3 \mathrm{H}), 8.62(1 \mathrm{H}), 8.29(2 \mathrm{H}), 8.03(1 \mathrm{H}), 7.92(1 \mathrm{H})$, $7.83(1 \mathrm{H}), 7.67(1 \mathrm{H}), 3.92(2 \mathrm{H}), 3.42(3 \mathrm{H}), 2.18(4 \mathrm{H}), 1.95(9 \mathrm{H})$. (See Figure $\mathrm{S} 10)$

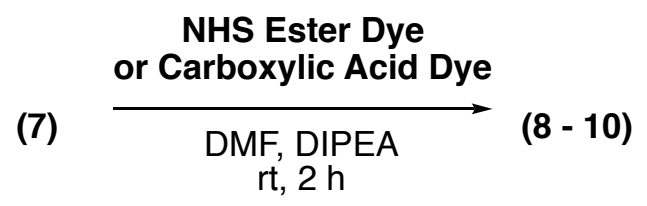

Synthesis of 8-9. 7 (1.9 mg, $0.0028 \mathrm{mmol}, 1.0 \mathrm{eq})$ and an NHS ester dye (3 eq) were suspended in DMF $(0.100 \mathrm{~mL})$. To this reaction DIPEA $(0.030 \mathrm{~mL}, 0.0082 \mathrm{mmol}, 3.0 \mathrm{eq})$ was added. The reaction was allowed to mix for 2 hours. After which the reaction was was purified via reverse phase chromatography. Fractions of similar purity were combined and concentrated to yield the desired product 8-9 (3 mg, $99 \%$ yield, 90 - 95 $\%$ purity) which was stored under $\mathrm{Ar}$ at $-80 \mathrm{C} . \mathrm{m} / \mathrm{z}$ calculated: 1103.52; (M)+ found: 1104.91 and $(\mathrm{M} / 2)^{+}$found: 543.08 . (See Figure S11 \& S12)

Synthesis of 10.7 (7.3 mg, $0.012 \mathrm{mmol}, 1.1 \mathrm{eq})$, HBTU $(8.3 \mathrm{mg}, 0.022 \mathrm{mmol}, 2 \mathrm{eq})$ and SiROOH dye $(5.5 \mathrm{mg}, 0.011 \mathrm{mmol}, 1.0 \mathrm{eq})$ were suspended in DMSO $(1.00 \mathrm{~mL})$. To this reaction DIPEA ( $4 \mathrm{uL}, 0.022 \mathrm{mmol}, 2 \mathrm{eq}$ ) was added. The reaction was allowed to mix for 2 hours. After which the reaction was was purified via reverse phase chromatography. Fractions of similar purity were combined and concentrated to yield the desired product 10 (79\% yield) which was stored under Ar at $-80 \mathrm{C}$. 


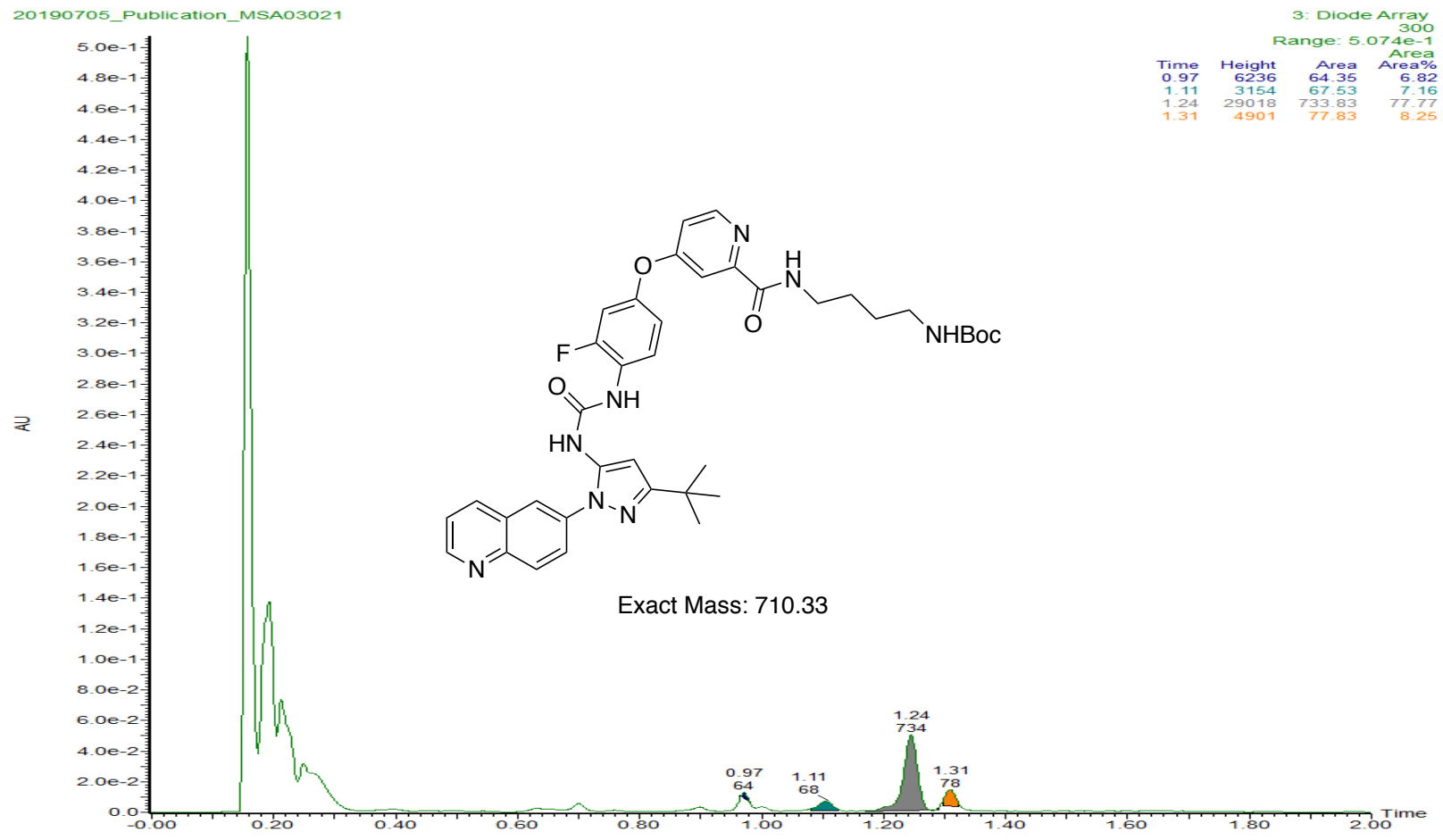

Figure S9: HPLC trace of 6 (77 \% Purity). 


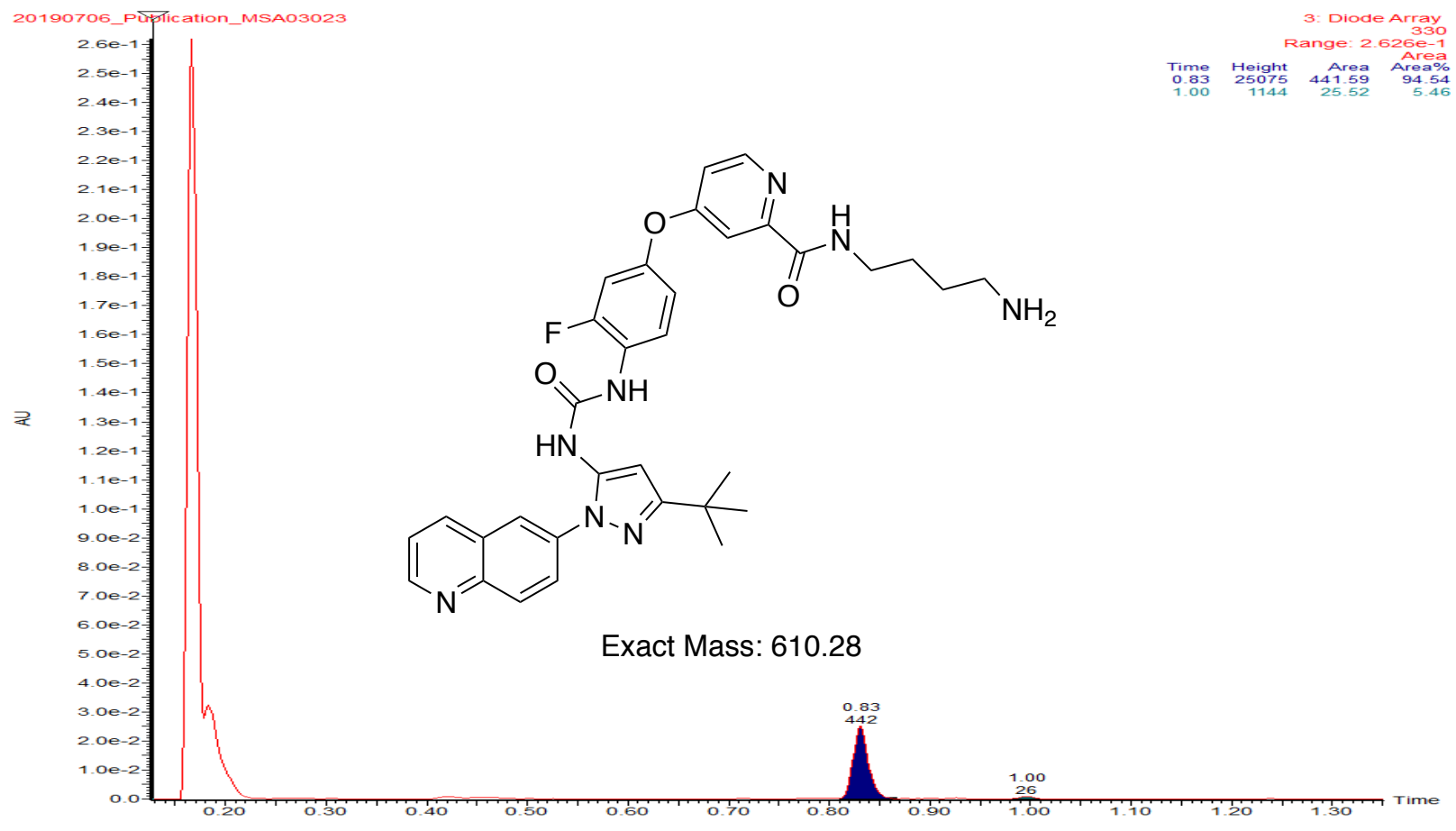

Figure S10: HPLC trace of 7 (95\% Purity). 


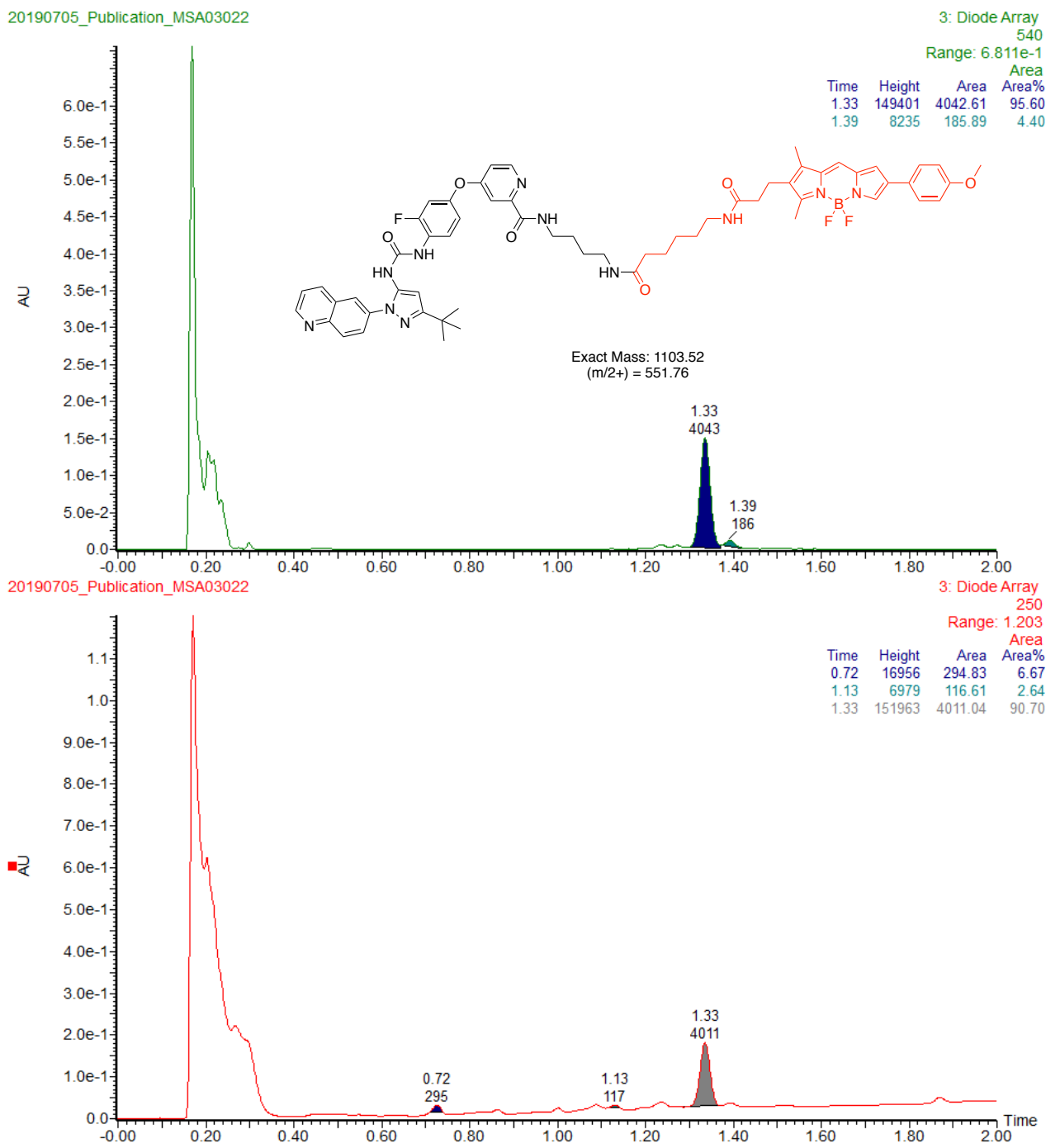

Figure S11: HPLC trace of 8 (90-95\% Purity). 


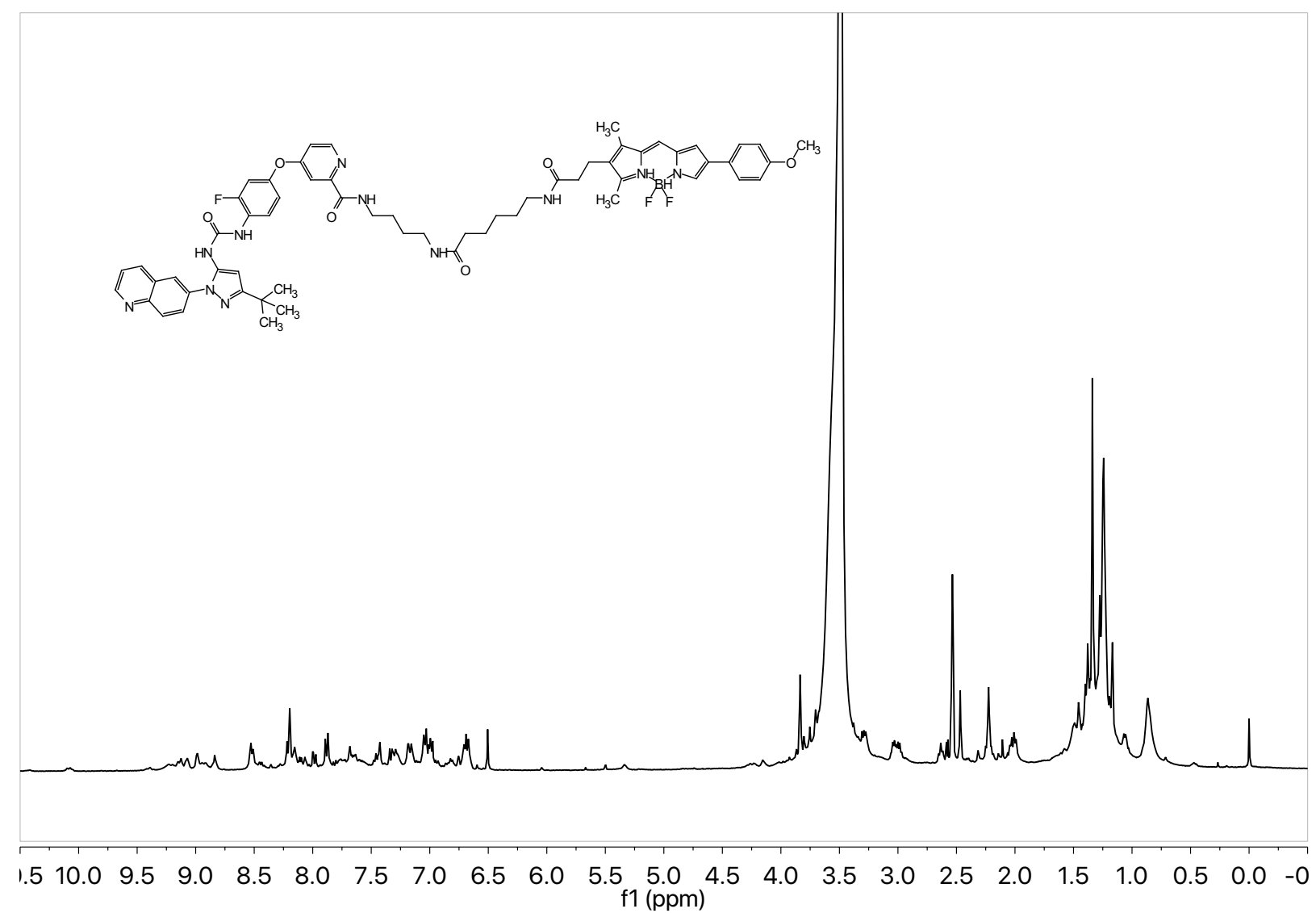

Figure S12: ${ }^{1} \mathrm{H}$ NMR of 8. 


\section{References}

1. Kim, E., Yang, K. S., Kohler, R. H., Dubach, J. M., Mikula, H. \& Weissleder, R. (2015) Optimized Near-IR Fluorescent Agents for in Vivo Imaging of Btk

Expression. Bioconjug Chem 26, 1513-1518

2. Lukinavičius, G., Umezawa, K., Olivier, N., Honigmann, A., Yang, G., Plass, T., Mueller, V., Reymond, L., Corrêa, I. R., Luo, Z. G., Schultz, C., Lemke, E. A., Heppenstall, P., Eggeling, C., Manley, S. \& Johnsson, K. (2013) A near-infrared fluorophore for live-cell super-resolution microscopy of cellular proteins. Nat Chem $5,132-139$

3. Lukinavičius, G., Blaukopf, C., Pershagen, E., Schena, A., Reymond, L., Derivery, E., Gonzalez-Gaitan, M., D’Este, E., Hell, S. W., Wolfram Gerlich, D. \& Johnsson, K. (2015) SiR-Hoechst is a far-red DNA stain for live-cell nanoscopy. Nat Commun 6,8497

4. Lukinavičius, G., Reymond, L., Umezawa, K., Sallin, O., D’Este, E., Göttfert, F., Ta, H., Hell, S. W., Urano, Y. \& Johnsson, K. (2016) Fluorogenic Probes for Multicolor Imaging in Living Cells. J Am Chem Soc 138, 9365-9368

5. Meimetis, L. G., Giedt, R. J., Mikula, H., Carlson, J. C., Kohler, R. H., Pirovich, D. B. \& Weissleder, R. (2016) Fluorescent vinblastine probes for live cell imaging. Chem Commun (Camb) 52, 9953-9956

6. Miller, M. A., Kim, E., Cuccarese, M. F., Plotkin, A. L., Prytyskach, M., Kohler, R. H., Pittet, M. J. \& Weissleder, R. (2017) Near infrared imaging of Mer tyrosine kinase (MERTK) using MERi-SiR reveals tumor associated macrophage uptake in metastatic disease. Chem Commun (Camb) 54, 42-45 